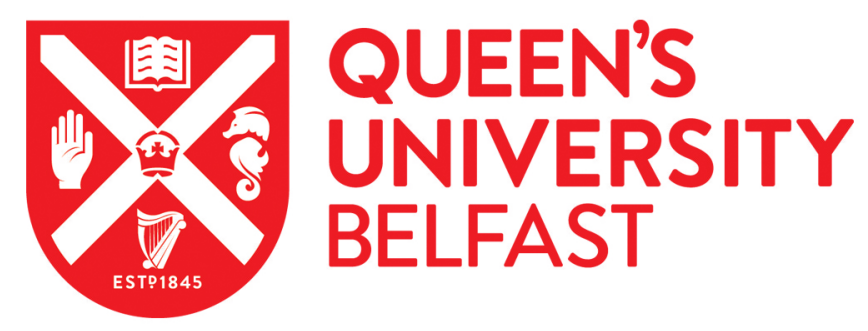

\title{
Foreign Policy as Ethics: Toward a Re-Evaluation of Values
}

Bulley, D. (2014). Foreign Policy as Ethics: Toward a Re-Evaluation of Values. Foreign Policy Analysis, 10(2). https://doi.org/10.1111/fpa.12003

\author{
Published in: \\ Foreign Policy Analysis
}

Document Version:

Peer reviewed version

Queen's University Belfast - Research Portal:

Link to publication record in Queen's University Belfast Research Portal

Publisher rights

(C) 2013 International Studies Association.

This is the peer reviewed version of the following article: Bulley, Dan. (2013) Foreign Policy as Ethics: Toward a Re-Evaluation of Values. Foreign Policy Analysis, which has been published in final form at http://onlinelibrary.wiley.com/doi/10.1111/fpa.12003. This article may be used for non-commercial purposes in accordance with Wiley Terms and Conditions for Self-Archiving.

\section{General rights}

Copyright for the publications made accessible via the Queen's University Belfast Research Portal is retained by the author(s) and / or other copyright owners and it is a condition of accessing these publications that users recognise and abide by the legal requirements associated with these rights.

Take down policy

The Research Portal is Queen's institutional repository that provides access to Queen's research output. Every effort has been made to ensure that content in the Research Portal does not infringe any person's rights, or applicable UK laws. If you discover content in the Research Portal that you believe breaches copyright or violates any law, please contact openaccess@qub.ac.uk. 


\title{
FOREIGN POLICY AS ETHICS: TOWARD A RE-EVALUATION OF VALUES
}

\author{
Dan Bulley \\ Senior Lecturer in International Relations \\ School of Politics, International Studies and Philosophy \\ Queen's University Belfast \\ d.bulley@qub.ac.uk
}

\section{Acknowledgements:}

An early version of this article was presented at the "Theorizing Foreign Policy in a Globalized World' Conference at Forschungskolleg Humanwissenschaften, Bad Homburg, Germany (1-4 July 2010). Thanks to the organisers of this conference, especially Gunther Hellman and Knud Erik Jorgensen who also made very useful comments on an earlier draft. The recommendations of the Editors and two anonymous referees also helped greatly in clarifying my argument. This article is dedicated to the memory of Dr Philippa Sherrington (1968-2011), a true inspiration on all things European. 


\begin{abstract}
$\underline{\text { Abstract: }}$
This article notes that while ethics is increasingly talked of in foreign policy, it remains a blind-spot for FPA. It argues that this must be rectified through a critical approach which conceptualises foreign policy as ethics. The first section examines how even constructivist approaches, which are highly attuned to the intersubjective sphere, still generally avoid dealing with morality. The second section looks at the possibilities and limits of one piece of constructivist theorizing that explores the translation of morality into foreign policy via 'norms'. This demonstrates the problems that a constructivist account, with its tendency toward explanatory description without evaluation, will always face. The final section argues, through an examination of EU foreign policy (from 1999-2004) and its innovative use of 'hospitality', that FPA must critically reassess the value of the norms and principles by which foreign policy operates in order to suggest potentially more ethical modes of encounter.
\end{abstract}

Globalization, whatever else it may mean and however thoroughgoing, involves increased levels of contact with the unfamiliar, the 'foreign'. According to Jan Aart Scholte $(2005,20)$, rising globality is about a 'growth of transplanetary and more particularly supraterritorial social relations'. These increased relations arguably breed more familiarity, making the 'foreign' appear less 'foreign' and thereby reducing the role for 'foreign policy' as such.' However, what I'm more interested in here is the idea that this rising contact with the unfamiliar has coincided with the end of the Cold War to incite discussion about precisely how we ought to relate to the foreign. In other words, foreign policy is engaging ethics, which Peter Singer $(1994,1)$ has argued are always a question of 'ought'. While the issue may never have in fact gone away (see, for example, McElroy 1992), from the 1990s we have seen a rising interest in the possibilities of ethics in foreign policy. As Leslie H. Gelb and Justine A. Rosenthal $(2003,2)$ have observed,

Something quite important has happened in American foreign policymaking with little notice or digestion of its meaning. Morality, values, ethics, universal principles the whole panoply of ideals in international affairs that were once almost the exclusive domain of preachers and scholars - have taken root in the hearts, or at least the minds, of the American foreign policy community. 
This has continued in US foreign policy with a stress upon the justice of war (O'Driscoll 2008), but the change has equally been marked in British (Little and Wickham-Jones 2000) and EU foreign policy (Lucarelli and Manners 2006; Bulley 2009). Perhaps ethics now seem 'more affordable' after the Cold War (Gelb and Rosenthal 2003, 5), but given that the results have been hugely unpopular wars in Afghanistan, Iraq and an apparent inability to deal with Darfur (Bellamy and Williams 2006) and Syria, the full 'digestion of its meaning' is more important than ever.

In spite of this, Foreign Policy Analysis (FPA), as the sub-discipline of International Relations (IR) that theorizes foreign policy explicitly, has singularly failed to even attempt such a digestion. IR has explored ethical theories and issues in greater depth, despite some 'false-starts' (Frost 1998, 124-129). From the early works of Charles R. Beitz (1979), through that of Chris Brown (1992) and Kimberly Hutchings (1999), IR has sought to draw out and define traditions and approaches to how international actors ought to behave. ${ }^{2}$ In recent years, a burgeoning array of IR literature has taken us beyond familiar dichotomies (such as cosmopolitanism and communitarianism; deontology and consequentialism) into virtue ethics (Gaskarth 2012), pragmatism (Cochran 1999; Brassett 2009), feminism (Hutchings 2007), just war theory (Bellamy 2006; Wheeler 2002), the natural law tradition (Boucher 2009; Cavallar 2002) and continental philosophy (Campbell 1998a; Der Derian 1997). IR has borrowed widely from a range of disciplines to define different conceptions of ought, whether that be in terms of ethical rules of conduct, the type of life to live, or the way we relate to and encounter others (Brown 2001, 20-21). Yet, seemingly ignoring the interdisciplinarity counted as one of its hallmarks (Hudson 2005, 2), FPA has had comparatively little to say on the topic.

In this article I ask why this is the case, and how ethics can be theorized more effectively in the realm of foreign policy by making the case for a critical approach. By a 'critical approach' I mean one which goes beyond describing the system of moral principles and ethical norms involved in foreign policies; one which also 'focuses on the grounds of that system's possibility' (Johnson 1981, xv), looking at the exercises of power that produced those ethics and how they can be, and are, politically contested. Ultimately, it seeks a re-evaluation of the values contained in foreign policy, asking how we might make them 'better'. This 'better' 
does not necessarily mean emancipation, as Critical Theorists would argue (Cox 1981); it seeks transformation but without a settled idea of what emancipation could mean. Like many of the critical approaches to ethics emerging from IR scholarship, I suggest that this 'better' cannot be ultimately grounded or finally established, but must be a matter of continual contestation and debate - ethics is political. As Brown argues, ethical principles often clash with each other and this requires a 'political argument that engages the issues directly' (Brown 2001, 26).

The article proceeds in three sections. Firstly, I ask how and why constructivist approaches, which are highly attuned to the intersubjective sphere of ideas and meanings of which ethics are necessarily a part, has generally avoided dealing with morality. Secondly, I examine the possibilities and limits of one piece of constructivist theorizing that effectively explores the apparent translation of morality into foreign policy via 'norms'. This demonstrates the problems that a constructivist account, unsupplemented by a more critical approach, will face when exploring the role of ethics. Finally, I argue that to effectively engage the issue we need to reconceptualise foreign policy as ethics. This provides a way into the problem of how we can 'better' relate ethically to the foreign, rather than just noting that we already do in certain respects. Through an examination of EU foreign policy (from 1999-2004), and its innovative use of 'hospitality', I suggest that FPA must reassess the value of the norms and principles by which foreign policy operates in order to suggest potentially more ethical modes of encounter.

\section{TRAINING TO IGNORE? MARGINALISING ETHICS IN FPA}

Theorizations of foreign policy have diversified a great deal in the last twenty years (Hudson 2005). While parts of the field (such as Sprout and Sprout 1965; Carlsnaes 1986) have always taken the ideational realm into account, Ole Waever $(1990,336)$ has noted that the field of FPA should extend its theorizations to other ideational factors relevant to foreign policy, those 'not in the individuals but in between them in a specific discourse space - the political sphere'. Those who really took up this challenge and ran with it were constructivists who argued that foreign policy is not simply made from individuals' beliefs and their interaction 
with the 'real world' of foreign policy. Rather, individuals helped form that world through their shared understandings of, and ideas about, it (Kubalkova 2001). The foreign policy world, like any other, is 'not entirely determined by physical reality', but is 'socially emergent' (Onuf 1998, 59). Thus the meaning is created, it does not just depend upon an external reality but also an intersubjective social reality made possible by social communication (Adler 1997, 326). Such meaning was to be found in 'specific discursive fields - and not just in bilateral subject-object relationships' (Waever 1990, 336).

This engagement with how foreign policy was made, at least in part, from intersubjectively created and shared ideas and meanings was a crucial breakthrough. Traditional FPA had failed to engage with the way that its theorizations of foreign policy had also been interpreting and perpetuating certain assumptions about foreign policy and the way it operated in world politics. As Roxanne Lynn Doty $(1993,298)$ noted, traditional FPA was engaged with asking why particular foreign policies were undertaken; in doing so, it presupposed a certain view of subjectivity and 'a background of social discursive practices and meanings which make possible the practices as well as the social actors themselves'. The fact that certain foreign policies could be undertaken therefore went unquestioned, and the ethical issues those policies raised were ignored.

A classic example is Graham Allison's seminal work, Essence of Decision (revised edition, 1999). Here, Allison sets himself the task of explaining three major policy decisions which produced the Cuban Missile Crisis of 1962: the Soviet decision to send missiles to Cuba; the US decision to blockade Cuba; and the Soviet decision to withdraw the missiles from Cuba. He explains why these decisions were taken via three 'models'. However, throughout his analysis the ethics of these decisions go unquestioned. But if, instead of asking such 'why' questions, we ask Doty's 'how-possible' questions (such as, how did it become possible for the US to decide to blockade Cuba?) important assumptions about the world are revealed (Doty 1993, 297-298). Most significantly, we see that the US was only able to take such a decision because they saw Cuba as lacking in sovereignty, as lacking the rights of a full sovereign state. Allison, in focusing on those specific moments of foreign policy and asking 'why', reproduces a vision of world politics in which Cuba's decisions are inconsequential and irrelevant to explaining the crisis which was ostensibly about Cuba. Thus Jutta Weldes' 
Constructing National Interests (1999) stands as a crucial riposte to Allison, engaging precisely the issues that Essence of Decision avoids. Weldes shows how constructivist FPA can, at its best, draw out the assumptions made both by foreign policy actors and FPA, assumptions which mean that ethical issues in relations with the likes of Cuba can simply be ignored.

Examining foreign policy as a socially produced and world producing practice, then, helps reveal that FPA is never value free. Rather, it necessitates certain concerns, methodologies, judgements and outcomes which are ethically and politically questionable. While the constructivist move to asking how the foreign policy world was created through shared meanings and ideas was crucial, it is important not to overstate it as a break from what went before. James Rosenau, perhaps the godfather of FPA, had already noted in 1987 that FPA concerns itself with politics at every level, with 'the full range of individual and collective processes whereby people seek to give meaning and hope to their lives' (Rosenau 1987, 3). Given his rationalist assumptions, Rosenau and traditional FPA lacked the conceptual tools to engage with these 'collective processes' by which meaning is generated (as demonstrated by the rest of the volume which he was introducing in 1987). But the inspiration clearly existed.

What is more surprising is that, given these insights, constructivist FPA has itself not gone on to discuss ethics in any sustained manner. Indeed, for the most part, this marginalisation of ethics has been a further continuity with traditional forms of FPA. But if foreign policy is about the intersubjective meanings and ideas that generate world politics, if FPA is about the 'full range' of individual and collective meanings, surely it must engage ethics at every turn? Instead, there has been a focus on 'values' and especially 'norms', both of which have a complex relation to ethics and morality (of which more below). This is a problem fully acknowledged by Paul Kowert (2001, 266): as he says, social science is necessarily 'an ethical as well as an explanatory process', yet constructivists 'are mostly silent about what kind of values constructivism itself might embrace. In this lacuna resides the untested promise of constructivism.' Yet, Kowert's deferral of this issue is exacerbated by his subsequent effacement of it; when considering the future, instead of suggesting that constructivists test their 'promise' regarding ethics, he simply suggests they 'push further down the same path' (2001, 279). 
Before I go on in the next section to discuss the treatment of norms in one particular case, I think it is important to ask why, and indeed how, constructivism has tended to perpetuate the marginalisation of ethical discussion from FPA. It must be noted that to generalise in this regard can only be for heuristic purposes, in order to try to get a handle on the issue. Generalizations about constructivism will never be accurate as there are as many different forms of the approach as there are constructivists (see Zehfuss 2002). Yet, perhaps we can say that the two main reasons have been, firstly, the character and aims of dominant modes of the approach to international politics and foreign policy; and secondly, the desire of many theorists to separate their work from that of poststructuralists.

Firstly, as Kubalkova $(2001,71)$ notes, constructivism does not try to provide a theory of foreign policy, and certainly does not try to offer a political theory of the international. It is neither 'problem-solving' nor 'critical' in Robert Cox's (1981) terms, and it is certainly not critical in the sense I outlined in the introduction. Instead, it is a general frame for understanding the social production of meaning. Thus, theorists such as Kublkova and Onuf stress the method of splitting our intersubjective social reality into different categories, such as rules, practices, institutions and so on (Onuf 1998). This is done so that social reality can be 'more fruitfully analysed' (Kubalkova 2001, 66). But what does 'more fruitfully analysed' mean? For what purpose? Karin Fierke $(2001,129)$ puts it succinctly when she observes that the goal of constructivism in IR must be 'constructing a better account of the past'. As such, constructivism can, and does, engage both traditional 'why' questions and 'how' questions. A 'better account' must tell us both why certain policies occurred and, at least to a certain degree, how they became possible in Doty's terms. But any further aim than this cannot come from constructivism itself as it does not necessarily embrace a critical agenda, or any form of ethical and political change. These, if they are to be endorsed, must come from elsewhere.

We can see this aim operating in Fierke's exploration of the Cold War's demise. She examines the irony of its end in that neither side's foreign policy aimed to achieve it; indeed, neither side wanted it, and yet the Western 'we've won' explanation nevertheless became dominant (Fierke 2001, 128). She suggests that poststructuralists, such as David Campbell, 
would merely explain this by pointing out that the 'powerful have once again succeeded in marginalizing and silencing voices' $(2001,128)$. While this is in itself a 'powerful argument', she suggests it has two limits: firstly, 'it suggests the game is over', the dominant voice won. Secondly,

There is little critical about this account except to demonstrate that we are all writings of the propaganda apparatus of the powerful. It does not tell us how the marginalized would be given more space to speak. More importantly, it does not give us any criteria for coming up with a better account of what happened. The argument is that multiple stories can always be told, although the story of the dominant tends to prevail. By contrast, we want to think about the criteria for constructing a better account of the past. (Fierke 2001, 128-129).

It is crucial to understanding the meaning of the end of the Cold war and how this 'constitutes our understanding of what is possible or necessary in the future'. But how, Fierke asks, do we judge a 'better' narrative of its end $(2001,133)$ ? For her, the 'we won' argument is of little use as it is an 'interpretation imposed after the fact'. In contrast, her constructivist 'conflicting games' argument is 'better' because it 'embeds the moves of any one actor in a larger intersubjective space and traces, over time, the transition from one game to another' $(2001,133)$. Constructivists therefore seek to categorise and trace changes in intersubjective meaning because it gives them a better grasp of this slippery social reality. This is 'more important' than telling us how marginalized figures could be given more space to speak. ${ }^{3}$

But if we judge an explanation of foreign policy based on its embeddedness in intersubjective space, is Fierke's account so clearly better? Presumably a Western 'we won' account could be so embedded. How then could we judge? A quantification of 'embeddedness' would surely show us little, if it were even possible. Therefore, simply because the 'we won' account's current formulation is poorly situated does not prevent it being potentially 'better'. Campbell $(1993,7-8)$ argues, in contrast to Fierke, that we should look to interpretation 'that acknowledges the improbability of cataloguing, calculating, and specifying "real causes", concerning itself instead with considering the manifest political 
consequences of adopting one mode of representation over another'. For Fierke, this leaves poststructuralists such as Campbell with no way of judging which account of the past is better, but in fact Campbell is explicit on this point: he suggests 'moral grounds' (1998a, 43). Narratives should be tested from case to case without universal criteria in terms of the relationship with the other they embody'. In this sense, narratives which glorify genocide can be judged 'worse' because they seek to destroy the identity of the other. On this criteria then, we can perhaps see Fierke's account of the Cold War's demise as 'better' than the 'we won' thesis because the latter implies the superiority of the self and is a way of degrading and belittling the other, with clear political and ethical consequences. It is not 'better' because its greater openness will generate better policy prescriptions (a liberal pluralist position), but because it is more ontologically responsible to the other, acknowledging a duty to and for the other born of its constitutive relation to the self (see Campbell 1998a; Bulley 2009).

So Campbell suggests a way of discerning better accounts of foreign policy while also engaging issues of ethics. Perhaps, however, it is the explicit desire of many constructivists to separate their work from that of poststructuralists like Campbell that has contributed to its perpetuating the marginalisation of ethics from analyses of foreign policy. Stefano Guzzini (2000, 148), for example, stresses the need to resist 'succumb[ing] to the sirens of postsructuralism', which 'is increasingly emptied of intelligible meaning'. The primary aim of providing better accounts of the past is also about trying to demonstrate that constructivism is 'compatible with good social science' (Adler 1997, 322), and justifying itself to the mainstream of the discipline. This then prompts the likes of Ben Tonra's polemical mischaracterisation of the middle ground it tries to stake out.

This constructivist turn does not go as far as post-structuralist approaches: those far countries of post-modernism where language is everything and there are no material constructs, only discourse. It does, however, offer a challenge to exclusively instrumental rationalist accounts. (Tonra 2003, 738)

While I do not dispute that a useful middle-ground has been carved out by constructivism, especially in the study of foreign policy, it is unfortunate that this has often been pursued by continuing the traditional marginalisation of ethics from FPA. 


\section{MORAL PRINCIPLES AND ETHICAL NORMS}

It would be wrong to suggest that those who take a constructivist approach to foreign policy do not examine ethics. Xavier Guillaume (2002) offered some very useful insights based on a Bakhtinian dialogical model. Yet, much more common is for constructivists to speak of 'values' in foreign policy, and especially 'norms'. These terms have most commonly been used in recent years in relation to EU foreign policy, which is seen to be, and exercise, a peculiarly 'normative power' (Manners 2002; see also Lucarelli and Manners 2006). This, Ian Manners $(2002$, 252) clarifies, means that not only does the EU shape what is 'normal' in international politics, but 'that the EU should act to extend its norms in the international system'. This sounds very much like the operation of ethics, which we are alerted to by an 'ought' statement (Singer 1994). Yet, Manners is not clear on the relation between ethics and norms. He has argued more recently that normative "does not mean the same as "ethical" but is part of being honest about why and how foreign policy is conducted' (Manners 2007, 118). In other words, the normative is less about ethics and more about, like Fierke, giving a 'better account' of foreign policy which, after all, is thoroughly normative. Yet, he also claims that it is about how things should he, about judging and directing human conduct (Manners 2007, 117-118), which, again, sounds a lot like ethics. The relation is ultimately left hanging.

Perhaps norms and the normative are felt to be in some sense 'safer', less risky, than talking about ethics and the ethical. Nonetheless, an excellent effort has been made to engage precisely this issue in the sometimes overlooked The Ethics of Destruction, by Ward Thomas (2001). Because of Thomas's ability to combine constructivist analysis with ethics, norms and foreign policy, he will be the focus of this section of the paper. While his work cannot be equated with the constructivist take on these issues (as noted above, there are as many constructivisms as there are constructivists), his is the only extended, book-length constructivist discussion of them, and helpfully highlights both the possibilities and limits of a constructivist analysis. Thomas also displays far more adeptness at linking and separating norms from ethics and morality than the likes of Manners. He makes a fundamental distinction between 'moral principles' and 'ethical norms'. A moral principle, he argues, is 'a 
proposition or tenet that expresses an abstract judgement about right and wrong' and is therefore necessarily very general. Ethical norms are 'less abstract corollaries, closer to the realm of action' (Thomas 2001, 27).

Such ethical norms are ethical to the extent that they are 'at least implicitly based upon or referring to a moral principle of one description or another' (Thomas 2001, 28). This is what separates ethical norms from the merely instrumental (those, for example, that maintain trade relations) or ritualistic (such as many diplomatic norms). In contrast, ethical norms are concerned with right and wrong, with judgement and prescription, because of the link they maintain to their moral principle. We can tell that they are specifically ethical norms because without this link it is difficult to account for their existence (Thomas 2001, 28). However, the separation between moral principles and ethical norms is fundamental for Thomas. While a moral principle can be held by one person, norms are necessarily intersubjective and require broader agreement. And while moral principles only suggest action by their abstract implication, ethical norms precisely and explicitly guide behaviour in the concrete realm of action.

This means that, while abstract moral principles are divested of power and politics by Thomas, norms are subject to interests and the calculations of states. This is what explains the often stark differences between the two:

For any principle to be operationalized as a norm it must move from the abstract realm of morality to the concrete realm of political action. In so doing it becomes subject to the calculations of states that, as realism reminds us, pursue their interests in a competitive environment. In the process the underlying moral imperative is often distorted or diluted. Moreover, because they are collective understandings and not abstract principles (that is, intersubjective rather than subjective phenomena), ethical norms derive their strength from the degree of consensus they enjoy and the level of commitment they engender. It is therefore impossible to discuss ethical norms without at least implicit reference to a power structure that constructs and maintains them. (Thomas 2001, 30) 
What Thomas is doing here is to separate morality from politics, and argue that norms are a kind of political ethics, though he does not use those terms. Thus ethics is subsumed into the very structure of international society by Thomas, as he argues that they both produce and are produced by state's interests. There is a constant loop feeding back between the two - between morality and politics - and this loop is the place of the ethical norm. This allows him to dismiss the neorealist critique that anarchy banishes ethics from foreign policy, because norms are in fact a constitutive part of the structure of anarchy.

Thomas (2001, 33-34) argues that there are two types of ethical norm: power-maintenance norms and convention-dependent norms. The former are those which basically support the existing power structure of international society (such as, he will go on to argue, the norm outlawing the assassination of foreign leaders) (Thomas 2001, 84). This gives powerful states a reason to respect the norm even if it does not appear to be in their immediate interests. However, because they are part of the structure of international society, no state can simply create a norm from nowhere; convention-dependent norms, which are based on reciprocity and precedent, thus partially evade their grasp. But because they are not based on powerful state's interests, once reciprocity or precedent are partially broken, they are much more easily set aside (as he goes on to demonstrate with aerial bombing in World War II) (Thomas 2001, 146). But even such convention-dependent norms inform a state's interests and are not easily abandoned. As he points out, violation of such norms damages international legitimacy and therefore the effectiveness of a state's power in international institutions - thus, damage to the moral status of a state 'creates a considerable structural disincentive to norm violation that must be weighed against the immediate advantage gained' (Thomas 2001, 36).

The undeniable strength of 'Thomas' argument is the manner in which he clearly sets out the way ethics are translated into the foreign policy behaviour of states, not just as a choice, but as a structural constraint and incentive to particular actions. And he does this in the very backyard of neorealism - the use of force. States generally comply with norms against certain uses of force because such norms 'define what and who they are, what they want and how they view international politics' (Thomas 2001, 17). Without such norms, power-maintaining though many are - there could be no explanation for the restraint shown by states in their use of force. And we could not understand these norms without two key elements: the moral 
principles upon which they are based; and the 'political processes', the 'considerations of power and interest, which often distort - but do not obliterate - moral principles' (Thomas 2001, 3).

Yet, there is still something missing to such an analysis of ethics and foreign policy. Thomas's project is the same as Fierke's - that of providing a 'better account' of the past. Frost $(1998,131)$ has noticed a similar concentration only on 'positive explanation' in Constructivist IR, which has generated a 'thoroughgoing descriptivism'. The problem is that, having pointed out the operation of norms there is no subsequent move to evaluate those norms (Frost 1998, 125). Thomas's focus on norms is born of no desire for more ethical or responsible foreign policies, however ethics/responsibility is conceived, but merely because ' $[u]$ nderstanding norms... allows us to understand aspects of international politics that would otherwise remain anomalous' (Thomas 2001, 195). There is no point of critique here, there is no attempt to transform the role of ethics and morality in norms, or the role of norms in foreign policy. Rather, Thomas' interest appears almost entirely instrumental - if we didn't look at norms, our account of certain policies would be insufficient or incomplete.

Thomas is highly attuned to the way power operates through norms and the way norms effectively exercise a form of power. But he is content to describe the operations of this power, rather than to suggest how it could be changed, or how power could be exercised otherwise. He notes that norms often ill-reflect the moral principles which help produce them and puts this down to operations of power and competition in the international system. Yet he seems unconcerned by this. No suggestion is made that this situation is unsatisfactory, or that anything could be done to improve the norm's reflection of morality. No mode is offered by which the value of these norms can be judged. They simply are. Thus, he is content to argue that we cannot expect moral altruism from states, that ethics is not an 'all-or-nothing proposition', and that, by implication, we should be content with this situation (Thomas 2001, 192). Of course, Thomas has set up a straw man here; I am aware of no scholar who would suggest that foreign policies can, or ought, to operate altruistically (see Brown 2001, 21). But by suggesting this as a key criticism of his argument, he swerves more wide-spread critical takes on the possibilities for international ethical action (for one excellent collection, see Campbell and Shapiro 1999). 
However, by separating the realm of ethics and morality proper (as abstract principles) from that of power, politics and action, and then building a bridge between the two in the form of norms, Thomas fails to see how politics and ethics are always already tied together. The moral principle he mentions, 'thou shalt not kill', has never applied to those outside the more or less bounded political community - as an Old Testament command this principle was never applied to the Canaanites, or any of the other nations massacred after it was literally set in stone. If Thomas had subjected moral principles to the same rigorous genealogical analysis provided for ethical norms, he would have found that morality and politics simply cannot be separated. Moral values are never held only by one person, as he suggests; if they were completely idiomatic, sharing nothing with what others believed or what had gone before, they would be utterly meaningless. In fact, moral principles are always intersubjective, social and political, reflecting a history of struggle and debate. If Thomas were to rigorously hold to his view of moral principles, they would have to be a pure metaphysical transcendental gift from God. But, as Friedrich Nietzsche (2000, 457) observed when engaging his own analysis of the struggle and contestation that generated Christian moral values, morality has never come 'out of the blue', but rather has emerged from a more 'vital' colour - 'namely gray'.

Thus Thomas's separation of morality from norms, and his purely descriptive mode of analysis without an element of critique, severely limits what can be done with his work. More importantly, perhaps, it also makes his analysis conservative. In questioning the limits of international ethics, Thomas notes that the 'statesman's duty' to his own national constituents is entirely understandable. It appears natural that in ethical terms... fellow citizens count more than foreigners to the statesman in his or her role as statesman... We do not expect a leader in such a situation to be blind to national distinctions' (Thomas 2001, 185186). He thus tacitly accepts and endorses a broadly communitarian ethic in which responsibility is territorialised, tied to a geographically defined national community. He notes that the statesman's duty does not mean that ethical obligations to non-nationals can be ignored (Thomas 2001, 186), but those duties are clearly not so important. Thomas is consistent in not taking a firm cosmopolitan or communitarian position, but he can also offer no thoughts on which values are valuable, and what might constitute a more ethical way of encountering and relating to the 'foreign'. 


\section{FOREIGN POLICY AS ETHICS}

If our contemporary theorizations of foreign policy are to deal effectively with issues of ethics, I am not convinced that an uncritical acceptance of norms is sufficient to the task. More is needed which can give us access to the way ethics necessarily impinges on all elements of foreign policy. Foreign policy makers do not face a choice 'whether or not to be ethical. We are ethically constrained in everything we do' (Frost 2001, 35). But we also need a way to consider the value of these ethical constraints. As Nietzsche $(2000,456)$ declared, 'we need a critique of moral values, the value of these values themselves must first be called in question'. Such ethical and moral values are essentially about how we ought to relate to others, to strangers, to those who are different, and to otherness in general - even otherness within our own community or our 'selves'. As such, values are not transcendent, but context-specific and intersubjective. Morality depends upon who and what the collective 'we' considers itself to be; who or what it constructs as other, as different to its 'self'; and how that 'we' envisages its obligations and duties to that other. There is no singular, general self or other, definable outside of context, and therefore there can be no singular, transcendental moral principles as Thomas implies. To speak of ethics is always to speak of how a subject ought to act in relation to a stranger, when both the subject and the stranger are produced in the moment of encounter.

But in order to re-evaluate the values of foreign policy, we require a conception of foreign policy which makes its ethical relation clear. David Campbell provides such a reconceputalisation in his reading of foreign policy as a politics of identity. He distinguishes between two understandings: what he calls 'foreign policy' and Foreign Policy (Campbell 1998b, 68-69). The broader practice of 'foreign policy' refers to discursive 'practices of differentiation or modes of exclusion (possibly figured as relationships of otherness) that constitute their object as "foreign" in the process of dealing with them' (Campbell 1998b, 68-69). This is foreign policy seen as a universal way of constituting 'domestic' and 'foreign' - of separating and excluding the 'foreign' from the 'domestic', the outside from the inside and the other from the self. Foreign Policy, meanwhile, is how IR and FPA generally 
conceive foreign policy: as a state-based practice directed toward that which is beyond the state's borders, that which is 'foreign' and not 'domestic'. The capitalised Foreign Policy is, therefore, a specific instance of the 'foreign policy' that we all perform each moment, both individually and collectively (see Bulley 2009).

This rethinking of foreign policy means that not only does it have a necessary ethical dimension, but the two are in fact concerned with the same matter. Both ethics and foreign policy are about how we constitute and relate to otherness, the foreign, even if that otherness appears as part of the 'self. If we have ethical responsibilities for our 'selves' individually or collectively - it is because we are acknowledging a divide within those selves: that which owes and that which receives the response. We are acknowledging the otherness within, that we are all more or less 'strangers to ourselves' (Kristeva 1994; Dillon 1999), our families and communities. Thus, any attempt to fully and finally separate the fields of ethics and foreign policy, or to 'join' them through the use of norms, is ultimately futile because both deal with precisely the same issue. The 'stuff' of ethics is foreign policy: it is about the way we ought to relate to otherness. And if foreign policy is a practice of constructing otherness and relating to it, the question of foreign policy must be how we ought to do this. Foreign policy is best viewed as ethics. Even when questions of 'ought' are not explicit in the practice of foreign policy, assumptions are made that presuppose a particular production of and relation to otherness, a specific 'self' and 'other', and the way they ought to relate.

A re-evaluation of the values that both produce and are produced in the moment of encounter that is foreign policy takes us beyond the 'better accounting' of constructivism. It demands that we pay great attention to the language of foreign policy to examine how the relationship to the foreign, the ethical relation, is being constructed and understood. This reveals unexpected results. It also requires that we explore how the norms and values which emerge empower and disempower the self and other, and whether 'better' forms of relation might be envisaged. This 'better' will necessarily always retain its 'scare quotes' as, having removed the transcendental metaphysics of ethics, having acknowledged what Andrew Linklater $(1998,48)$ calls the impossibility of 'occupying an Archimedean standpoint which permits objective knowledge of permanent moral truths', we place morality squarely in the realm of the political. As such, the relation must be kept open to contestation, re-evaluation 
and critique. Nonetheless, it allows the possibility of a more ethical encounter with the foreign than is perhaps currently possible under existing norms and values that are often taken for granted.

Various examples of such re-evaluations can be seen in contemporary critical explorations of international ethical concepts, throughout different disciplines. For instance, in critical legal scholarship, Costas Douzinas (2007) has examined the link between an ethics of human rights policies and the violence of liberal cosmopolitanism, while Anne Orford (1999; 2003) has critiqued the narratives of heroism that appear throughout Western states' humanitarian interventions. In International Political Economy James Brassett (2010) challenges the simplistic ethics of global justice ubiquitous amongst social movements while, in IR, Maja Zehfuss (2007) illustrates the problematic invocations of the 'tragic' in claims to just wars, and I have argued for the necessary irresponsibility of a responsibility to protect (Bulley 2010). All these claims to ethical relations (human rights, humanitarian intervention, global justice, just war and responsibility) call for more exploration by FPA. However, the example I want to look at here is taken from EU foreign policy, as I believe it best illustrates the way a critical approach can reveal unexpected values and logics at the heart of foreign policy as ethics.

The period from 1999-2004 was a time of great innovation in EU foreign policy, with the key jobs held by Romano Prodi (President of the Commission), Chris Patten (External Relations Commissioner) and Javier Solana (High Representative for the Common Foreign and Security Policy). These key figures were joined, as Prodi (2003a) put it, by the belief in 'an ethical dimension to politics' (see also Prodi 2002d). While a global ethical responsibility was enunciated to a certain degree by the EU (Prodi 2004b), it was stressed frequently during this period that the EU bears its greatest responsibility for those 'neighbours' who are geographically proximate (for a few examples, see Solana 2000b; Solana 2000d; Solana 2004; Patten 2002).

However, what marks the EU out as singular with regard to its conception of international ethics is how that 'responsibility' was to be exercised. Rather than through humanitarian intervention or foreign aid, which was how British foreign policy during this period 
exercised its notion of ethical responsibility (see Bulley 2010), the EU privileged an ethics of hospitality. While, like any collective subject, the EU requires the exclusion of others, in this period it chose to express this by emphasising those others to be newly included. Three foreign policies were particularly key in this respect: the enlargement of the EU toward Central and Eastern Europe (which occurred in 2004 and 2007 with a total of 12 new countries being welcomed into the EU), preparations for a proposed further enlargement toward the Balkans, and the new European Neighbourhood Policy (ENP). The discourse surrounding these policies was replete with references to the ethical necessity of welcoming such others to the European 'family', and the 'door' being open to the European 'home' (for example, Prodi 1999; Prodi 2002a; Patten 2001; Solana 2003). Enlargement in particular was presented as a political, economic and 'moral imperative' (Solana 2000a; Solana 2000c). As Patten observed, ' $[\mathrm{w}]$ hat better way could there have been of treating a neighbour than inviting them into our home?' (Patten 2005, 117).

Hospitality, while not a concept much explored in international politics or foreign policy (Bulley 2006), is a mode of ethical relation with a long and venerable tradition (Bolchazy 1977; Cavallar 2002; Brown 2010). At its most basic, hospitality can perhaps be defined as an openness toward strangers, a welcoming of the foreign into the home, the domestic. As such, it is a clear example of foreign policy as ethics - hospitality is a way of producing and relating a self and an other. Moreover, this relation is commonly expressed as a good and thus as an ought, especially by the EU. However, significant problems arise with any definition of hospitality due to its aporetic, or inherently contradictory structure, and we can read this problem through its use in EU foreign policy. Firstly, even the most hospitable and open policy during this period, that of enlargement, was never an unconditional offer of welcome. Jacques Derrida has specified (in Derrida and Dufourmantelle 2000, 25) that an ethics of unconditional hospitality, where one takes the concept to its limit,

... requires that I open up my home and that I give not only to the foreigner... but to the absolute, unknown, anonymous other, and that I give place to them, that I let them come, that I let them arrive, and take place in the place I offer them, without asking of them either reciprocity (entering into a pact) or even their names. 
The EU's enlargement and its policy toward the Balkans make no attempt to achieve this. In order to receive a positive opinion from the Commission on its application to join the EU, the first step of the process, a country must be a European state and respect the principles of liberty, democracy, human rights and fundamental freedoms and the rule of law. Part of this process involves countries answering a questionnaire of over 2,500 questions before accession negotiations could even begin, something Prodi stressed to the Croatian Parliament in 2003 (Prodi 2003b). This is obviously far from Derrida's unconditional 'no questions asked'. Following a positive opinion, any country seeking the EU's hospitality must fulfil the 'Copenhagen Criteria' set by the European Council in 1993: the stability of institutions guaranteeing democracy, the rule of law and respect for human rights; maintain a fully functioning market economy with an ability to cope with competitive pressures from the single market; and the capacity to take on the obligations of membership, including the aims of political, economic and monetary union. Far from lacking conditions, the EU's hospitality is replete with detailed requirements before welcome can occur.

However, secondly, the ENP develops this highly conditional form of hospitality into an almost overt hostility. While friendliness and welcome is demonstrated, exclusion is the inspiration behind the ENP. Throughout 1999-2004, the EU was struggling to produce a policy toward what were to become its 'new neighbours' after the enlargements. In January 2004, Prodi finally announced the ENP as a cpartnership based on shared values and enhancing economic development, interdependence and cultural links for those neighbours for which accession is not on the agenda' (Prodi 2004a - emphasis added). The explicit agenda this resulted from was as an answer to the question Prodi asked in 2002: 'where does Europe stop?', a desire not to welcome the foreign (Prodi 2002b). The ENP was envisaged as an offer to share 'everything but institutions' (Prodi 2002b) with countries surrounding the EU (such as Georgia and Azerbaijan). These partners, Patten $(2005,142)$ claimed, are 'welcome to set up their stall in the marketplace, but not set foot in the townhall'.

There is also a third problem with regard to hospitality as a mode of ethical praxis in EU foreign policy. While the EU's hospitality may be seen as too conditional, even if an unconditional openness to the foreign were possible that openness would risk destroying the 
very home which enables hospitality in the first place. Hospitality relies and depends upon a bounded space into which a subject can welcome the stranger, that which does not 'belong'. But welcoming the foreign into the domestic makes it no longer, in a pure sense, the domestic any longer. It is no longer just 'my' home, but the home of the other as well. And should all strangers be allowed in, the home would no longer be a bounded space which anyone can call their 'own'. Thus, Prodi (2002c) is right to say that continued enlargement risks 'water[ing] down the European political project and turn[ing] the European Union into just a free trade area on a continental scale'. This is no surprise to someone like Thomas $(2001,192)$ who, as we saw, argued that an ethical norm is inevitably a 'watered-down' version of a moral principle because of its translation through power and politics. But the difference here is that even the moral principle itself, unconditional hospitality, is shown to be contested and inherently political. For hospitality to operate at all, in any context, it requires hostility and exclusion in order to maintain the home as a bome. Without that hostility complete openness destroys the home and, with it, an ethics of hospitality.

The necessarily contested character of ethical concepts does not mean that they should be abandoned. Nor does it mean that rigorous social science should content itself with only describing the difficulties. Rather, the re-evaluation of values should drive us to ask different questions, all with the aim of negotiating a 'better', less hostile, more responsible relation to the other. It opens up every aspect of the policy to reappraisal: Is hospitality really a mode of relation that we should privilege? Is Derrida (2001, 16-17) right to claim that, inasmuch 'as it has to do with the ethos, that is, the residence, one's home... the manner in which we relate to ourselves and to others... as foreigners, ethics is hospitality'? Would another moral principle be more appropriate? What kind of power relations are in operation between the EU and accession countries? Can we reconsider the conditions placed upon the EU's hospitality (the initial requirements and subsequent Copenhagen Criteria)? Are they too severe? And with all the talk of uniform conditions, a singular, single-track 'road to Europe' (Patten 2000), is there room for variation, to allow for differential welcomes to countries with different requirements, as happened with Spain and Portugal in the past (Redmond 2007)? Can other strangers be welcomed by the EU, those that are not already formed into states? Could the EU imagine a way of offering a form of hospitality to the Kurds? 
This is not to say that a foreign policy can ever simply be ethical or hospitable, but rethinking foreign policy as ethics leaves the possibility open for a 'better' relation to the foreign. As stated above, this 'better' can never have its scare quotations removed, as it is specific to a time and place, a self and an other, and must always be open for reassessment. Added to this, abandoning a metaphysical basis for ethics means that the very way of judging the 'better' must be kept under continual contestation. However, conceptualising foreign policy as ethics does allow opportunities beyond accounting for the role of ethics in foreign policy. It proffers a mode of critique, a way of assessing current values and practices for the relation they produce to the foreign. Thus we can examine current EU practices toward the Balkan countries or toward Turkey and question the way these subjects are being produced as 'foreign' and the conditions that are being placed upon their accession. But we are also offered the possibility of transforming these relations through this critique. While such a transformation would have to be hedged, as allowing countries into the EU will always be a risk, the possibility of moving toward a more ethical relation, perhaps, remains.

\section{CONCLUSION}

The aim of this paper has been to suggest that theorizations of foreign policy need to engage the tricky issue of ethics. The guiding principle of such endeavour is not, however, like Gelb and Rosenthal, that of reaching a 'values consensus'. After all, on many issues as Thomas demonstrates, Western foreign policies have already inadvertently reached such a consensus. Instead, I have stressed the importance of three key moves. Firstly, I argue that we need to theorize ethics as a constituent part of foreign policy, to examine foreign policy as always expressing an ethics in the way that it produces a 'self and an 'other', a 'domestic' and a 'foreign', and the way they ought to relate. Secondly, I argued that, in doing this, there is a need to go further than simply accounting for the role that ethics currently play in foreign policy. Beyond such understanding, we perhaps require a critical perspective which moves toward re-evaluating the values that are expressed in foreign policies through norms and ideas. 
Finally, I claimed that a more critical perspective should be oriented toward making 'our' relation to the 'foreign' in some way 'better', more responsible, while acknowledging that it can never achieve an unproblematic, fully ethical mode of encounter. A values consensus in this sense is less useful than a politics of foreign policy as ethics. A respectful dissensus, disagreement, contestation and debate are where any hope for 'better' relations may lie. Rather than a simple pluralism however, which as William Connolly (1995, xiv) says is often presented as an achievement which a pluralisation of approaches threatens, reading foreign policy as ethics seeks a ceaseless critical responsiveness to the foreign in the permanent absence of consensus.

\section{NOTES}

\footnotetext{
${ }^{1}$ An argument made by former British Foreign Office minister Peter Hain (2001) in suggesting an end to traditional British foreign policy and, in its stead, a Department for
} Global Affairs.

2 I use the terms 'ethical' and 'moral' interchangeably, following Hutchings' (1996) argument that the distinction drawn between the two by scholars such as Jurgen Habermas (and, indeed, by Ward Thomas later in this article) is untenable.

${ }^{3}$ Parenthetically, Fierke's criticisms of Campbell are misplaced to say the least. Firstly, Campbell far from implies that the 'game is over' by problematizing our reading of the Cold War and suggesting that, in fact, its dominant mode of identity construction has been perpetuated in US foreign policy (Campbell 1998b, 15), a point that has been borne out by the so-called 'war on terror'. But secondly, one can only claim that Campbell does not suggest means for allowing marginalized voices to speak by ignoring the large parts of his work that specifically problematize dominant voices (see particularly Campbell 1998a, 115208) and seek to provide them more space to speak (see Campbell 1998a, 209-243).

${ }^{4}$ Martha Finnemore and Kathryn Sikkink have a similar conception of 'norms' in international society, arguing that they are both descriptive and prescriptive of what is and should be normal. In fact, it is their evaluative character, the 'oughtness' they inspire, that alerts us to the presence of a norm (see Finnemore and Sikkink 1992, 891-892). 


\section{REFERENCES}

AdLER, EMmANUEL. 1997. "Seizing the Middle Ground: Constructivism in World Politics." European Journal of International Relations 3: 319-363.

AlLISON, GRAHAM and PHILIP ZELIKOW. 1999. Essence of Decision: Explaining the Cuban Missile Crisis, $2^{\text {nd }}$ ed. New York: Longman.

BeItz, Charles R. 1979. Political Theory and International Relations. Princeton:

Princeton University Press.

Bellamy, Alex and Paul D. Williams. 2006. "The UN Security Council and the Question of Humanitarian Intervention in Darfur." Journal of Military Ethics 5: 144-160.

Bellamy, Alex J. 2006. Just Wars: From Cicero to Iraq. Cambridge: Polity Press.

Bolchazy, LadisLaus J. 1977. Hospitality in Antiquity: Livy's Concept of its

Humanizing Force. Chicago: Ares Publishers Inc.

BOUCHER, DAVID. 2009. The Limits of Ethics in International Relations: Natural Law, Natural Rights, and Human Rights in Transition. Oxford: Oxford University Press.

Brassett, James. 2009. "A Pragmatic Approach to the Tobin Tax Campaign: The Politics of Sentimental Education." European Journal of International Relations.

BRASSETT, JAMES. 2010. Cosmopolitanism and Global Financial Reform: A Pragmatic Approach to the Tobin Tax Campaign. London: Routledge.

BROWN, CHRIS. 1992. International Relations Theory: New Normative Approaches. New York: Columbia University Press.

BROwn, ChrIs. 2001. "Ethics, interests and foreign policy." In Ethics and Foreign Policy, eds. Karen E. Smith and Margot Light. Cambridge: Cambridge University Press.

Brown, Garrett WallaCe. 2010. "The Laws of Hospitality, Asylum Seekers and Cosmopolitan Right: A Kantian Response to Derrida." European Journal of Political Theory 9: 308-327.

Bulley, Dan. 2006. "Negotiating Ethics: Campbell, Ontopology and Hospitality." Review of International Studies 32: 645-663. 
Bulley, DAN. 2009. Ethics as Foreign Policy: Britain, the EU and the Other. London: Routledge.

BULLEY, DAN. 2010. "The politics of ethical foreign policy: A responsibility to protect whom?" European Journal of International Relations 16: 441-461.

CAMPBell, David and Michael J. Shapiro, eds. 1999. Moral Spaces: Rethinking Ethics and World Politics. Minneapolis: University of Minnesota Press.

CAmpBell, DAVID. 1993. Politics without Principle: Sovereignty, Ethics and the Narratives of the Gulf War. Boulder, CO: Lynne Rienner.

CAMPBELl, DAVID. 1998a. National Deconstruction: Violence, Identity and Justice in Bosnia. Minneapolis: University of Minnesota Press.

CAMPBell, DAVID. 1998b. Writing Security: United States Foreign Policy and the Politics of Identity. Manchester: Manchester University Press.

Carlsnaes, Walter. 1986. Ideology and Foreign Policy: Problems of Comparative Conceptualization. Oxford: Basil Blackwell.

CAVAllar, GeORG. 2002. The Rights of Strangers: Theories of International Hospitality, the Global Community and Political Justice Since Vitoria. Aldershot: Ashgate.

Cochran, Molly. 1999. Normative Theory in International Relations: A Pragmatic Approach. Cambridge: Cambridge University Press.

Connolly, William E. 1995. The Ethos of Pluralization. University of Minnesota Press: Minneapolis.

COX, ROBERT W. 1981. "Social Forces, States and World Orders: Beyond International Relations Theory.” Millennium: Journal of International Studies 10: 126-155.

DER DERIAN, JAMES. 1997. "Post-Theory: The Eternal Return of Ethics in International Relations.” In New Thinking in International Relations Theory, eds. Michael Doyle and John Ikenberry. New York: Westview Press.

DERRIDA, JACQUES and ANNE DufOURMANTELLE. 2000. Of Hospitality, trans. Rachel Bowlby. Stanford: Stanford University Press.

DERRIDA, JACQUES. 2001. On Cosmopolitanism and Forgiveness, trans. M. Dooley and M. Hughes. London: Routledge. 
Dillon, Michael. 1999. 'The Sovereign and the Stranger.' In Sovereignty and Subjectivity, eds. Jenny Edkins, Nalini Persram and Veronique Pin-Fat. Boulder: Lynne Rienner.

Doty, Roxanne LynN. 1993. "Foreign Policy as Social Construction: A Post-Positivist Analysis of US Counterinsurgency Policy in the Philippines." International Studies Quarterly 37: 297-320.

DOUZINAS, Costas. 2007. Human Rights and Empire: The Political Philosophy of Cosmopolitanism. London: Routledge.

FIERKE, KARIN M. 2001. "Critical Methodology and Constructivism.” In Constructing International Relations: The Next Generation, eds. Karin M. Fierke and Knud Erik Jorgensen. New York: M.E. Sharpe.

FinNeMORE, MARTHA and KATHRYN SiKKINK. 1992. "International Norm Dynamics and Political Change.” International Organization 52: 887-917.

Frost, Mervyn. 1998. "A turn not taken: Ethics in IR at the Millennium." Review of International Studies 24: 119-132.

FROST, MERVYN. 2001. "The ethics of humanitarian intervention: protecting civilians to make democratic citizenship possible.” In Ethics and Foreign Policy, eds. Karen E. Smith and Margot Light. Cambridge: Cambridge University Press.

GASKARTH, JAMIE. Forthcoming. "The Virtues in International Society.” European Journal of International Relations. 18, forthcoming.

Gelb, Leslie H. and Justine A. Rosenthal. 2003. "The Rise of Ethics in Foreign Policy: Reaching a Values Consensus." Foreign Affairs 82: 2-7.

Guillaume, Xavier. 2002. "Foreign Policy and the Politics of Alterity: A Dialogical Understanding of International Relations." Millennium: Journal of International Studies 31: 1-26.

GuZZINI, STEFANO. 2000. "A Reconstruction of Constructivism in International Relations." European Journal of International Relations 6: 147-182.

HaIN, Peter. 2001. The End of Foreign Policy? Britain's Interests, Global Linkages and Natural Limits. London: The Fabian Society/Green Alliance/The Royal Institute for International Affairs. 
Hudson, VAlerie M. 2005. "Foreign Policy Analysis: Actor-Specific Theory and the Ground of International Relations.” Foreign Policy Analysis 1: 1-30.

Hutchings, Kimberly. 1996. Kant, Critique and Politics. London: Routledge.

HutChings, Kimberly. 1999. International Political Theory London: Sage.

HutChIngs, KimBerly. 2007. "Feminist Ethics and Political Violence.” International Politics 44: 90-106.

JOHNSON, BARBARA. 1981. “Translator's Introduction.” In Jacques Derrida, Dissemination, trans. Barbara Johnson. Chicago: University of Chicago Press. KOWERT, PAUL. 2001. “Towards a Constructivist Theory of Foreign Policy”. In Foreign Policy in a Constructed World, ed. Vendulka Kubalkova. New York: M.E. Sharpe. KristeVA, JuliA. 1994. Strangers to Ourselves. New York: Columbia University Press. Kubalkova, VendulKa. 2001. “A Constructivist Primer.” In Foreign Policy in a Constructed World, ed. Vendulka Kubalkova. New York: M.E. Sharpe.

LinKLATER, ANDREW. 1998. The Transformation of Political Community. Cambridge: Polity Press.

LitTle, Richard and MARK WiCKHAM-Jones, eds. 2000. New Labour's Foreign Policy: A New Moral Crusade? Manchester: Manchester University Press.

LuCARElli, Sonia and IAn Manners, eds. 2006. Values and Principles in European Union Foreign Policy. London: Routledge.

MANNERS, IAN. 2002. "Normative Power Europe: A Contradiction in Terms?” Journal of Common Market Studies 40: 235-258.

MANNERS, IAN. 2007. “European Union, normative power and ethical foreign policy.” In Rethinking Ethical Foreign Policy: Pitfalls, Possibilities and Paradoxes, eds. David Chandler and Volker Heins. London: Routledge.

McElroy, Robert W. 1992. Morality and American Foreign Policy: The Role of Ethics in International Affairs. Princeton NJ: Princeton University Press.

NIETZSCHE, FRIEDRICH. 2000. On the Genealogy of Morals, ed. and trans. Walter Kauffmann. Basic Writings of Nietzsche. New York: The Modern Library. O'DrisCOLl, CIAN. 2008. The Renegotiation of the Just War Tradition and the Right to War in the Twenty-First Century. Basingstoke: Palgrave MacMillan. 
ONUF, NiCHOLAS. 1998. “Constructivism: A Users Manual.” In Vendulka Kubalkova, Nicholas Onuf and Paul Kowert, eds. International Relations in a Constructed World. New York: M.E. Sharpe.

ORFORD, ANN. 1999. "Muscular Humanitarianism: Reading the Narratives of the New Interventionism.” European Journal of International Law 10: 679-711.

ORFORD, ANN. 2003. Reading Humanitarian Intervention: Human Rights and the Use of Force in International Law. Cambridge: Cambridge University Press.

PAtTEN, Chris. 2000. Speech to the Foreign Affairs and Legal Committees of the Albanian Parliament, Tirana, 6 March.

PATTEN, ChRIS. 2001. "A voice for Europe? The future of the CFSP.” Brian Lenihan Memorial Lecture, Dublin, 7 March

PATten, Chris. 2002. "Developing Europe's External Policy in the Age of Globalisation.” Speech at Central Party School, Beijing, 4 April.

PATTEN, Chris. 2005. Not Quite the Diplomat: Home Truths about World Affairs. London: Allen Lane.

Prodi, Romano. 1999. Speech to the EU-Japan Business Dialogue Roundtable, Brussels, 7 October.

Prodi, Romano. 2002a. "The EU, the UK and the world." Speech to Said Business School, Oxford, 29 April.

Prodi, RomAnO. 2002b. "Europe in transition: hopes and fears." Speech at Fifth Europa Forum: "Europe facing the decision - EU Enlargement and Global Challenges", Brussels, 3 December.

Prodi, Romano. 2002c. "A Wider Europe - A Proximity Policy as the key to stability." Speech at Sixth ECSA-World Conference, Brussels, 5-6 December

Prodi, Romano. 2002d. "Europe and Ethics." Speech to the Conference on Politics and Morality, Vienna, 7 December.

PRODI, RomanO. 2003a. Report to the European Parliament on the Spring European Council, Brussels. 26 March.

PRODI, RomANO. 2003b. “Croatia's journey towards EU membership.2 Speech to Croatian Parliament, Zagreb, 10 July. 
PRODI, RomANO. 2004a. Speech on visit to Bogazici University, Istanbul, 16 January.

Prodi, Romano. 2004b. Speech to European Parliament, Strasbourg, 10 February.

REDMOND, JoHN, 2007. "Turkey and the European Union: troubled European or

European trouble." International Affairs 83: 305-317.

Rosenau, JAMES N. 1987. "Introduction: New Directions and Recurrent Questions in the Comparative Study of Foreign Policy." In New Directions in the Study of Foreign Policy, eds. C.F. Hermann, Charles W. Kegley Jr, and James N. Rosenau. Boston: Allen \& Unwin.

SChOlte, JAN AART. 2005. Globalization: A Critical Introduction, 2nd ed. Basingstoke: Palgrave.

Singer, Peter, ed. Ethics. Oxford: Oxford University Press, 1994.

SOLANA, JAVIER. 2000a. Speech to the Fernandez Ordonez Seminar, 14 January.

Solana, JAVIER. 2000b. "Some Reflections About European Foreign Policy." Address to the Adam Mickiewicz University, Poznan, 12 February.

SOLANA, JAVIER. 2000c. "Towards a Stronger Alliance.” European Affairs, 12 April.

SOLANA, JAVIER. 2000d. "The Foreign Policy of the EU." Speech at the Liberal International, The Hague, 7 November.

Solana, JaVIER. 2003. Interview with Dnevi Avaz (BiH newspaper), 24 September.

SOLANA, JAVIER. 2004. Address to the National Forum on Europe, Dublin Castle, 8 January.

Sprout, Harold and Margaret Sprout. 1965. The Ecological Perspective on Human Affairs: With Special Reference to International Politics. Princeton: Princeton University Press.

THOMAS, WARD. 2001. The Ethics of Destruction: Norms and Force in International Relations. Ithaca: Cornell University Press.

TonRA, Ben. 2003. "Constructing the Common Foreign and Security Policy: The Utility of a Cognitivist Approach.” Journal of Common Market Studies 41: 731-756.

WAEVER, Ole. 1990. "Review Essay: The Language of Foreign Policy." Journal of Peace Research 27: 335-343. 
Weldes, JutTA. 1999. Constructing National Interests: The United States and the Cuban Missile Crisis. Minneapolis: University of Minnesota Press.

WheELER Nicholas J. and Tim DunNe. 2004. "Moral Britannia? Evaluating the Ethical Dimension in Labour's Foreign Policy." London: Foreign Policy Centre. <http://fpc.org.uk/fsblob/233.pdf > (2009, May 25).

WHEELER, NiCHOLAS J. 2002. Saving Strangers: Humanitarian Intervention in International Society. Oxford: Oxford University Press.

ZeHFuss, MAJA. 2002. Constructivism in International Relations: The Politics of Reality. Cambridge: Cambridge University Press.

ZEHFusS, MAJA. 2007. "The Tragedy of Violent Justice: The Danger of Elshtain's Just War Against Terror." International Relations 27: 493-501. 